\title{
Polymorphisms in Pattern-Recognition Genes in the Innate Immunity System and Risk of Non-Hodgkin Lymphoma
}

\author{
Wei Hu ${ }^{1}{ }^{\star}$, , Bryan A. Bassig ${ }^{1}$, Jun $\mathrm{Xu}^{1}$, Tongzhang Zheng ${ }^{2}$, Yawei Zhang ${ }^{2}$, Sonja I. Berndt ${ }^{1}$, \\ Theodore R. Holford ${ }^{2}$, H. Dean Hosgood III ${ }^{1}$, Brian Leaderer ${ }^{2}$, Meredith Yeager ${ }^{1}$, Idan \\ Menashe $^{1}$, Peter Boyle ${ }^{3}$, Kaiyong Zou ${ }^{4}$, Yong Zhu ${ }^{2}$, Stephen Chanock ${ }^{1}$, Qing Lan ${ }^{1}$, \\ Nathaniel Rothman ${ }^{1}$
}

${ }^{1}$ Division of Cancer Epidemiology and Genetics, National Cancer Institute, NIH, DHHS, Bethesda, Maryland ${ }^{2}$ Division of Environmental Health Sciences, Yale University School of Public Health, New Haven, Connecticut ${ }^{3}$ International Agency for Research on Cancer, Lyon, France ${ }^{4}$ Department of Molecular, Cellular, and Developmental Biology, Yale University, New Haven, Connecticut

\section{Abstract}

The pattern-recognition pathway plays an important role in infection recognition and immune responses, and previous studies have suggested an association between genetic variation in innate immunity genes and non-Hodgkin lymphoma (NHL). We evaluated NHL risk associated with genetic variation in pattern-recognition genes using data from a case-control study of NHL conducted in Connecticut women. Single nucleotide polymorphisms (SNPs) in 27 patternrecognition genes were genotyped in 432 Caucasian incident NHL cases and 494 frequencymatched controls. Unconditional logistic regression was used to compute odds ratios (ORs) for NHL and common NHL subtypes in relation to individual SNPs and haplotypes. A gene-based analysis that adjusted for the number of tagSNPs genotyped in each gene showed a significant association with over-all NHL for the $M B P$ gene $(P=0.028)$, with the diffuse large B-cell lymphoma (DLBCL) subtype for the MASP2 gene ( $P=0.011)$, and with the follicular lymphoma (FL) subtype for $D E F B 126(P=0.041)$. A SNP-based analysis showed that $M B P$ rs8094402 was associated with decreased risks of overall NHL (allele risk OR $=0.72, P$-trend $=0.0018$ ), DLBCL (allele risk $\mathrm{OR}=0.72, P$-trend $=0.036$ ), and $\mathrm{FL}$ (allele risk $\mathrm{OR}=0.67, P$-trend $=0.021$ ), while $M A S P 2$ rs 12711521 was associated with a decreased risk of DLBCL (allele risk $\mathrm{OR}=0.57, P$ trend $=0.0042$ ). We also observed an increased risk of FL for DEFB126 rs6054706 (allele risk OR $=1.39, P$-trend $=0.033$ ). Our results suggest that genetic variation in pattern-recognition genes is

\footnotetext{
"Correspondence to: Wei Hu, National Cancer Institute, Division of Cancer Epidemiology and Genetics, Environmental and Occupational Epidemiology Branch, 6120 Executive Blvd, EPS 5103, Bethesda, MD 20892-7240. wei.hu@ @ih.gov. AUTHOR CONTRIBUTIONS

Drs T. Zheng, Y. Zhang, T. Holford, P. Boyle, S. Cha-nock, Q. Lan, N. Rothman, S. Berndt, B. Leaderer, M. Yeager, K. Zou, and Y. Zhu were involved in the conception and design of the study. Drs W. Hu, B. Bassig, J. Xu, D. Hosgood, I. Menashe, Q. Lan, and N. Rothman conducted data analysis and/or were involved in the interpretation of the data and results. Drs W. Hu, B. Bassig, J. Xu, Q. Lan, and N. Rothman wrote the first draft of the manuscript and/or assisted in the preparation of the final manuscript. All the listed authors have reviewed and approved the final version of the manuscript.

Additional Supporting Information may be found in the online version of this article.
} 
associated with the risk of NHL or specific NHL subtypes, but these preliminary findings require replication in larger studies.

\section{Keywords}

pattern recognition; NHL; MBP; MASP2; innate immunity

\section{INTRODUCTION}

Prior epidemiological evidence has indicated that some infections may increase the risk of non-Hodgkin lymphoma (NHL). The incidence of NHL is 70 times greater in HIV-infected individuals than in the general population [Grulich et al., 2007], and NHL is classified as an AIDS-defining criterion [Epeldegui et al., 2010]. In particular, several case-control studies including a large pooled study from InterLymph have suggested a moderate, but consistent association of hepatitis C virus (HCV) infection with an increased risk in NHL [de Sanjose et al., 2008; Franceschi et al., 2011]. Furthermore, there is evidence in chronic hepatitis C patients of enhanced genetic expression of genes related to NHL, strongly suggesting the possible relationship between chronic HCV infection and B-lymphomagenesis [Ito et al., 2010]. A similar association was observed in a population with confirmed chronic hepatitis B virus infection [Engels et al., 2010].

The innate immunity system is the first line of host defense to clear nonspecific antigens after exposure to microorganisms and interacts with the adaptive immune system during physiological and chronic inflammation [Kabelitz and Medzhitov, 2007]. The general strategy of innate immune detection is to recognize microbial molecules that are conserved across broad taxa by a limited number of receptors [Beutler, 2004]. Pattern-recognition receptors (PRR) of the innate immune system recognize invariant structures, which are referred to as pathogen-associated molecular patterns (PAMPs). PAMPs are perceived by the innate immune system as signs of infection, and their recognition via PRR induces an immune response [Friese et al., 2004].

The association between NHL risk and immune dysfunction may be modified by variation in genes involved in the regulation of the immune system [Cerhan et al., 2007]. A previous study that examined variants within genes associated with immunity and inflammation and risk of NHL using a panel of 9,412 single-nucleotide polymorphisms (SNPs) from 1,253 genes did identify several genes important in the inflammatory and innate immune response, including TRAF, RIPK3, BAT2, and TLR6, which were associated with the risk of NHL or specific subtypes [Cerhan et al., 2007]. A few studies also provide evidence that genetic variation in immune response and innate immunity genes are associated with NHL [Forrest et al., 2006; Lan et al., 2006; Purdue et al., 2007; Rothman et al., 2006; Wang et al., 2007; Cerhan et al., 2009] and with subtypes of NHL [Di Bernardo et al., 2008; Skibola et al., 2009; Crowther-Swanepoel et al., 2010; Lan et al., 2010]. However, few studies have comprehensively examined the association between pattern-recognition genes and lymphoma risk except for only focusing on toll-like receptors, a group of PRRs [Nieters et al., 2006; Purdue et al., 2009]. 
To test the hypothesis that genetic variation in pattern-recognition genes is associated with lymphomagenesis, we evaluated genetic polymorphisms in 27 pattern-recog-nition genes and 285 SNPs using data from a case-control study of women conducted in Connecticut.

\section{METHODS}

\section{Study Population}

Detailed methods of this case-control study of NHL have been previously described [Lan et al., 2006]. Briefly, the study included female patients aged 21-84 years-old with histologically confirmed NHL (ICD-O: M-9590-9642, 9690-9701, and 9740-9750) who were identified from the Yale Comprehensive Cancer Center's Rapid Case Ascertainment Shared Resource and without a previous diagnosis of cancer except for nonmelanoma skin cancer. Population-based controls with a Connecticut address were identified through random digit dialing ( $<65$ years of age) or via files from the Health Care Financing Administration ( $\searrow 65$ years of age). Study controls were frequency matched to cases by age in 5-year strata. Participation rates for study controls were $69 \%$ for those contacted via random digit dialing and 47\% among those identified through medical records. From 1995 to 2005,601 eligible NHL cases (72\% of all eligible cases) and 717 qualified controls participated in this study.

Informed consent was obtained for each participant who agreed to participate in the study, and the study was reviewed and approved by the Institutional Review Board at Yale University, the Connecticut Department of Public Health, and the National Cancer Institute (NCI).

\section{Blood Samples and Genotyping}

At the time of the interview, eligible blood samples were obtained from 461 (76.7\%) consenting cases and 535 (74.6\%) consenting controls, and DNA was extracted from samples using a phenol-chloroform extraction method. Genotyping was conducted at the NCI Core Genotyping Facility (Advanced Technology Center, Gaithersburg, MD) using an Illumina GoldenGate platform. DNA from 448 cases and 525 controls was successfully genotyped. Duplicate samples from 100 study participants and 40 replicate samples from each of the two blood donors were interspersed throughout the plates used for genotype analysis for quality-control purposes. In total, 285 SNPs from 27 pattern-recognition genes were considered. The completion rate for all SNPs was greater than $97 \%$, and the concordance rate for quality control samples was greater than $95 \%$ for all assays.

\section{Statistical Analysis}

For each SNP, Hardy-Weinberg equilibrium (HWE) was assessed in non-Hispanic white controls using a chi-square test. SNPs with a $P$-value $>0.01$ from the chi-square test were considered to be in HWE. To test for an association with NHL at the gene level, a minimum $P$-test ("minP") based on permutation resampling was conducted to assess the true statistical significance of the smallest $P$-trend within each gene region [Chen et al., 2006]. This approach adjusts for the number of tagSNPs tested within each gene region as well as the underlying linkage disequilibrium pattern [Chen et al., 2006]. The minP test was 
additionally conducted for the most prevalent NHL subtypes in the study population, including diffuse large B-cell lymphoma (DLBCL; 32.4\%), follicular lymphoma (FL; $23.8 \%$ ), marginal zone lymphoma (MZL; 6.7\%), and chronic lymphocytic leukemia/small lymphocytic lymphoma (CLL/SLL; 11.3\%).

Unconditional logistic regression was used to estimate odds ratios (ORs) and calculate 95\% confidence intervals (CIs) for individual SNPs and NHL, adjusted for age. The models compared the variant allele homozygote and heterozygote to the common allele homozygote, which served as the reference group. A linear trend test assuming an additive genetic model was conducted by assigning an ordinal value of 1,2 , or 3 corresponding to the homozygous wild-type, heterozygote, and homozygous variant genotype, respectively. These scores were then modeled as a continuous variable. Stratified analyses by NHL subtype were conducted for DLBCL, FL, MZL, and CLL/SLL, using all controls in order to maximize statistical power. The false-discovery rate (FDR) was applied to the minP test in order to account for multiple comparisons ( $P<0.2$ considered significant). We examined the haplotype block structure for pattern-recognition genes that were significant in the overall or subtype analysis using Haploview 4.2. Individual haplotype frequencies were estimated using the expectation-maximization algorithm [Excoffier and Slatkin, 1995], and unconditional logistic regression was used to estimate the effect of individual haplotypes, using the most frequent haplotype as the reference group. All analyses in this study were limited to Caucasians for a final sample size of 432 cases and 494 controls. Statistical analysis was conducted using Statistical Analysis Software version 9.1.3 (SAS Institute Cary, NC).

\section{RESULTS AND DISCUSSION}

Of the 285 SNPs tested, 4 were not in HWE (Supporting Information Table SII) However, none of the significant findings were located in these genes. Cases and controls were similar with respect to age, level of education, and having a family history of cancer (Table I).

The $M B P$ (myelin basic protein) gene region was significantly associated with overall NHL in gene level analyses ( $P=0.028$; Supporting Information Table SI). In addition, there was evidence of an association with DLBCL for $\operatorname{MASP2}(P=0.011)$ and with FL for the DEFB126 $(P=0.041)$ gene regions (Supporting Information Table SI). However, none of these significant associations at the gene level identified from the minP test withstood adjustment for the FDR.

The most significant SNPs within these genes are shown in Tables II and III. MBP rs8094402 was associated with a significantly decreased risk of overall NHL (per allele risk $\mathrm{OR}=0.72,95 \% \mathrm{CI}=0.58-0.88, P$-trend $=0.0018$; Table II) and the DLBCL (per allele risk $\mathrm{OR}=0.72,95 \% \mathrm{CI}=0.53-0.98, P$-trend $=0.036$; Table II) and FL subtypes (per allele risk $\mathrm{OR}=0.67,95 \% \mathrm{CI}=0.47-0.94, P$-trend $=0.021$; Table II) $]$, adjusted for age. The $M B P G G$ homozygous variant genotype (referent $=\mathrm{AA}$ and $\mathrm{AG}$ ) was significantly associated with a decreased risk of overall NHL ( $\mathrm{OR}=0.35,95 \% \mathrm{CI}=0.21-0.59, P=0.000069)$, while no significant association was observed for the $M B P A G$ genotype (Table II). Furthermore, the decrease in risk associated with the $M B P \mathrm{GG}$ genotype was statistically significant for the 
DLBCL $(\mathrm{OR}=0.14,95 \% \mathrm{CI}=0.04-0.47, P=0.0013)$ and $\mathrm{FL}(\mathrm{OR}=0.27,95 \% \mathrm{CI}=0.09$ $0.76, P=0.013$ ) subtypes (Table II), but not for MZL ( $\mathrm{OR}=0.54,95 \% \mathrm{CI}=0.12-2.32, P=$ 0.40 ) or CLL/SLL (OR $=0.30,95 \% \mathrm{CI}=0.07-1.26, P=0.10$; Table III). A decreased risk of the DLBCL subtype for MASP2 rs 12711521 (allele risk OR $=0.57,95 \% \mathrm{CI}=0.39-0.84$, $P$-trend $=0.0042$; Table II) and an increased risk of the FL subtype for DEFB126 rs6054706 (allele risk $\mathrm{OR}=1.39,95 \% \mathrm{CI}=1.03-1.88, P$-trend $=0.033$; Table II) were further observed.

After adjustment for multiple comparisons using the FDR, however, only the $M B P \mathrm{GG}$ genotype remained statistically significant. Haplotype analyses were consistent with the results of the individual SNP analyses and did not provide additional insight into these associations (data not shown).

We found that several SNPs in genes involved in the pattern-recognition pathway were associated with overall NHL risk or specific NHL subtypes in women. Our results extend the existing knowledge that genetic variation in genes of the innate immune system may confer susceptibility to NHL, and our comprehensive evaluation of the pattern-recognition pathway specifically indicates that variation in these genes may be important with respect to lymphomagenesis. In particular, our results are suggestive of a potential role of the $M B P$ and $M A S P 2$ genes in overall NHL risk as well as for the DLBCL subtype.

Golli-myelin basic proteins encoded by $M B P$ are found in both the immune system and the nervous system of humans. Previous evidence has indicated that golli-MBP acts as an autoantigen and plays a role in T-cell function and specifically may regulate T-cell activation [Feng, 2007]. Golli proteins have been shown to negatively regulate T-cell activation through modulation of calcium homeostasis [Feng et al., 2006]. T-cells are part of the innate immune response, as they express a restricted T-cell receptor repertoire, which is used as a PRR [Holt-meier and Kabelitz, 2005]. Therefore, genetic variation in MBP resulting in differential expression of MBP protein could influence the immune response by either enhancing or inhibiting T-cell activation. A previous study that examined polymorphisms in genes involved in innate immunity and susceptibility to benzene-induced hemato-toxcity indicated that variation in the $M B P$ gene was significantly associated with white blood cells counts [Shen et al., 2011]. Several studies have also indicated that $M B P$ is associated with cancer risk. Specifically, a case-control study of breast cancer in Korean women indicated that the $M B P$ gene was associated with breast cancer [Lee et al., 2009], and $M B P$ was also significantly associated with childhood leukemia risk after correction for multiple comparisons [Han et al., 2010].

MASP2, a serine protease, plays an important role in the activation of the complement system via mannose-binding lectin [Medzhitov and Janeway, 2000; Ip et al., 2009], as it translates the recognition of microorganisms by pattern-recognition molecules, that is, MBL, $\mathrm{H}$-ficolin, L-ficolin, and M-ficolin, into initiation of the complement system [Thiel et al., 2009]. It was previously reported that variation in complement genes may be related to NHL risk, and given the involvement of the complement system in infectious and inflammatory processes, the complement system may be related to lymphomagenesis [Bassig et al., 2012]. A study of 106 donor-patient sibling pairs undergoing conventional myeloablative allogeneic 
stem-cell transplantation has shown that polymorphisms responsible for MASP2 deficiency are independent predictive factors for invasive fungal infections following allo-SCT [Granell et al., 2006]. Higher MASP2 was also associated with better event-free survival in pediatric patients with hematologic malignancies, especially lymphoma [Zehnder et al., 2009].

The protein encoded by the $D E F B 126$ gene is a member of the beta defensin protein family. Defensins are cysteine-rich cationic polypeptides that play a role in host defense from invading microorganisms and are catego rized as either $a$-defensins or $\beta$-defensins [Yang et al., 1999]. $\beta$-Defensins have been demonstrated to interact with the chemokine receptor CCR6 and may have a role in initiating the adaptive immune response [Yang et al., 1999]. There is limited previous evidence concerning disease associations with the DEFB126 genetic region, specifically, although a study of glioma susceptibility observed a significant association with the $D E F B 126 / 127$ genetic region in analyses restricted to glioblastoma [Rajaraman et al., 2009].

In conclusion, we observed an association at the gene level with $M B P$ for overall NHL and with $M A S P 2$ and $D E F B 126$ for DLBCL and FL, respectively. Although our study was of modest size for a rare cancer, we lacked the statistical power to fully consider specific NHL subtypes, and therefore our results require replication. Nevertheless, our results are suggestive of a potential role of PRRs in susceptibility to overall NHL or for specific NHL subtypes, particularly for $M B P$ and $M A S P 2$. To our knowledge, this is the first study to comprehensively evaluate genetic variation in pattern-recognition pathway genes and risk of NHL. However, because of the small sample size, future studies with a larger number of subtype specific cases should evaluate these associations more closely.

\section{Supplementary Material}

Refer to Web version on PubMed Central for supplementary material.

\section{ACKNOWLEDGMENT}

We gratefully acknowledge the assistance of Peter Hui (Information Management Services, Silver Spring, MD) for programming support.

\section{REFERENCES}

Bassig BA, Zheng T, Zhang Y, Berndt SI, Holford TR, Hosgood HD III, Hu W, Leaderer B, Yeager M, Menashe I, Boyle P, Xu J, Zou K, Zhu Y, Chanock S, Rothman N, Lan Q. 2012 Polymorphisms in complement system genes and risk of non-Hodgkin lymphoma. Environ Mol Mutagen 53:145-151. [PubMed: 22170086]

Beutler B. 2004 Innate immunity: An overview. Mol Immunol 40:845-859. [PubMed: 14698223]

Chen BE, Sakoda LC, Hsing AW, Rosenberg PS. 2006 Resampling-based multiple hypothesis testing procedures for genetic case-control association studies. Genet Epidemiol 30:495-507. [PubMed: 16755536]

Cerhan JR, Ansell SM, Fredericksen ZS, Kay NE, Liebow M, Call TG, Dogan A, Cunningham JM, Wang AH, Liu-Mares W, Macon WR, Jelinek D, Witzig TE, Habermann TM, Slager SL. 2007 Genetic variation in 1253 immune and inflammation genes and risk of non-Hodgkin lymphoma. Blood 110:4455-4463. [PubMed: 17827388] 
Cerhan JR, Novak AJ, Fredericksen ZS, Wang AH, Liebow M, Call TG, Dogan A, Witzig TE, Ansell SM, Habermann TM, Kay NE, Slager SL. 2009 Risk of non-Hodgkin lymphoma in association with germline variation in complement genes. Br J Haematol 145:614-623. [PubMed: 19344414]

Crowther-Swanepoel D, Mansouri M, Enjuanes A, Vega A, Smedby KE, Ruiz-Ponte C, Jurlander J, Juliusson G, Montserrat E, Catovsky D, Campo E, Carracedo A, Rosenquist R, Houlston RS. 2010 Verification that common variation at $2 \mathrm{q} 37.1,6 \mathrm{p} 25.3,11 \mathrm{q} 24.1,15 \mathrm{q} 23$, and $19 \mathrm{q} 13.32$ influences chronic lymphocytic leukaemia risk. Br J Haemaltol 150:473-479.

de Sanjose S, Benavente Y, Vajdic CM, Engels EA, Morton LM, Bracci PM, Spinelli JJ, Zheng T, Zhang Y, Franceschi S, Talamini R, Holly EA, Grulich AE, Cerhan JR, Hartge P, Cozen W, Boffetta P, Brennan P, Maynadie M, Cocco P, Bosch R, Foretova L, Staines A, Becker N, Nieters A. 2008 Hepatitis $C$ and non-Hodgkin lymphoma among 4784 cases and 6269 controls from the International Lymphoma Epidemiology Consortium. Clin Gastroenterol Hepatol 6:451-458. [PubMed: 18387498]

Di Bernardo MC, Crowther-Swanepoel D, Broderick P, Webb E, Sellick G, Wild R, Sullivan K, Vijayakrishnan J, Wang Y, Pittman AM, Sunter NJ, Hall AG, Dyer MJ, Matutes E, Dearden C, Mainou-Fowler T, Jackson GH, Summerfield G, Harris RJ, Pettitt AR, Hillmen P, Allsup DJ, Bailey JR, Pratt G, Pepper C, Fegan C, Allan JM, Catovsky D, Houlston RS. 2008 A genome-wide association study identifies six susceptibility loci for chronic lymphocytic leukemia. Nat Genet 40:1204-1210. [PubMed: 18758461]

Engels EA, Cho ER, Jee SH. 2010 Hepatitis B virus infection and risk of non-Hodgkin lymphoma in South Korea: A cohort study. Lancet Oncol 11:827-834. [PubMed: 20688564]

Epeldegui M, Vendrame E, Martinez-Maza O. 2010 HIV-associated immune dysfunction and viral infection: Role in the pathogenesis of AIDS-related lymphoma. Immunol Res 48:72-83. [PubMed: 20717742]

Excoffier L, Slatkin M. 1995 Maximum-likelihood estimation of molecular haplotype frequencies in a diploid population. Mol Biol Evol 12:921-927. [PubMed: 7476138]

Feng JM. 2007 Minireview: Expression and function of golli protein in immune system. Neurochem Res 32:273-278. [PubMed: 17024569]

Feng JM, Hu YK, Xie LH, Colwell CS, Shao XM, Sun XP, Chen B, Tang H, Campagnoni AT. 2006 Golli protein negatively regulates store depletion-induced calcium influx in T cells. Immunity 24:717-727. [PubMed: 16782028]

Forrest MS, Skibola CF, Lightfoot TJ, Bracci PM, Willett EV, Smith MT, Holly EA, Roman E. 2006 Polymorphisms in innate immunity genes and risk of non-Hodgkin lymphoma. Br J Haematol 134:180-183. [PubMed: 16740140]

Franceschi S, Lise M, Trepo C, Berthillon P, Chuang SC, Nieters A, Travis RC, Vermeulen R, Overvad K, Tjonneland AM, Olsen A, Bergmann M, Boeing H, Kaaks R, Becker N, Trichopoulou A, Lagiou P, Bamia C, Palli D, Sieri SA, Panico S, Tumino R, Sacerdote C, Bueno-de-Mesquita HB, Peeters PH, Rodriguez L, Lujan Barroso L, Dorronsoro M, Sanchez MJ, Navarro C, Barricarte Gurrea A, Regner S, Borgquist S, Melin B, Hallmans G, Khaw KT, Wareham NJ, Rinaldi S, Hainaut P, Riboli E, Vineis P. 2011 Infection with hepatitis B and C viruses and risk of lymphoid malignancies in the European Prospective Investigation into Cancer and Nutrition (EPIC). Cancer Epidemiol Biomarkers Prev 20:208-214. [PubMed: 21098651]

Friese MA, Steinle A, Weller M. 2004 The innate immune response in the central nervous system and its role in glioma immune surveillance. Onkologie 27:487-491. [PubMed: 15585981]

Granell M, Urbano-Ispizua A, Suarez B, Rovira M, Fernandez-Aviles F, Martinez C, Ortega M, Uriburu C, Gaya A, Roncero JM, Navarro A. Carreras E, Mensa J, Vives J, Rozman C, Montserrat E, Lozano F. 2006 Mannan-binding lectin pathway deficiencies and invasive fungal infections following allogeneic stem cell transplantation. Exp Hematol 34:1435-1441. [PubMed: 16982337]

Grulich AE, van Leeuwen MT, Falster MO, Vajdic CM. 2007 Incidence of cancers in people with HIV/ AIDS compared with immunosup-pressed transplant recipients: A meta-analysis. Lancet 370:5967. [PubMed: 17617273]

Han S, Lan Q, Park AK, Lee KM, Park SK, Ahn HS, Shin HY, Kang HJ, Koo HH, Seo JJ, Choi JE, Ahn YO, Chanock SJ, Kim H, Rothman N, Kang D. 2010 Polymorphisms in innate immunity genes and risk of childhood leukemia. Hum Immunol 71:727-730. [PubMed: 20438785] 
Holtmeier W, Kabelitz D. $2005 \gamma \delta$ T cells link innate and adaptive immune responses. Chem Immunol Allergy 86:151-183. [PubMed: 15976493]

Ip WK, Takahashi K, Ezekowitz RA, Stuart LM. 2009 Mannose-binding lectin and innate immunity. Immunol Rev 230:9-21. [PubMed: 19594626]

Ito M, Murakami K, Suzuki T, Mochida K, Suzuki M, Ikebuchi K, Yamaguchi K, Mizuochi T. 2010 Enhanced expression of lymphomagenesis-related genes in peripheral blood B cells of chronic hepatitis C patients. Clin Immunol 135:459-465. [PubMed: 20189883]

Kabelitz D, Medzhitov R. 2007 Innate immunity-Cross-talk with adaptive immunity through pattern recognition receptors and cytokines. Curr Opin Immunol 19:1-3. [PubMed: 17157490]

Lan Q, Zheng T, Rothman N, Zhang Y, Wang SS, Shen M, Berndt SI, Zahm SH, Holford TR, Leaderer B, Yeager M, Welch R, Boyle P, Zhang B, Zou K, Zhu Y, Chanock S. 2006 Cytokine polymorphisms in the Th1/Th2 pathway and susceptibility to non-Hodgkin lymphoma. Blood 107:4101-4108. [PubMed: 16449530]

Lan Q, Au WY, Chanock S, Tse J, Wong KF, Shen M, Siu LP, Yuenger J, Yeager M, Hosgood HD 3rd, Purdue MP, Liang R, Rothman N. 2010 Genetic susceptibility for chronic lymphocytic leukemia among Chinese in Hong Kong. Eur J Haematol 85:492-495. [PubMed: 20731705]

Lee JY, Park AK, Lee KM, Park SK, Han S, Han W, Noh DY, Yoo KY, Kim H, Chanock SJ, Rothman N, Kang D. 2009 Candidate gene approach evaluates association between innate immunity genes and breast cancer risk in Korean women. Carcinogenesis 30:1528-1531. [PubMed: 19372141]

Medzhitov R, Janeway C Jr. 2000 Innate immunity. N Engl J Med 343:338-344. [PubMed: 10922424]

Nieters A, Beckmann L, Deeg E, Becker N. 2006 Gene polymorphisms in Toll-like receptors, interleukin-10, and interleukin-10 receptor $a$ and lymphoma risk. Genes Immun 7:615-624. [PubMed: 16971956]

Purdue MP, Lan Q, Kricker A, Grulich AE, Vajdic CM, Turner J, Whitby D, Chanock S, Rothman N, Armstrong BK. 2007 Polymorphisms in immune function genes and risk of non-Hodgkin lymphoma: Findings from the New South Wales non-Hodgkin Lymphoma Study. Carcinogenesis 28:704-712. [PubMed: 17056605]

Purdue MP, Lan Q, Wang SS, Kricker A, Menashe I, Zheng TZ, Hartge P, Grulich AE, Zhang Y, Morton LM, Vajdic CM, Holford TR, Severson RK, Leaderer BP, Cerhan JR, Yeager M, Cozen W, Jacobs K, Davis S, Rothman N, Chanock SJ, Chatterjee N, Armstrong BK. 2009 A pooled investigation of Toll-like receptor gene variants and risk of non-Hodgkin lymphoma. Carcinogenesis 30:275-281. [PubMed: 19029192]

Rajaraman P, Brenner AV, Butler MA, Wang SS, Pfeiffer RM, Ruder AM, Linet MS, Yeager M, Wang Z, Orr N, Fine HA, Kwon D, Thomas G, Rothman N, Inskip PD, Chanock SJ. 2009 Common variation in genes related to innate immunity and risk of adult glioma. Cancer Epidemiol Biomarkers Prev 18:1651-1658. [PubMed: 19423540]

Rothman N, Skibola CF, Wang SS, Morgan G, Lan Q, Smith MT, Spinelli JJ, Willett E, De Sanjose S, Cocco P, Berndt SI, Brennan P, Brooks-Wilson A, Wacholder S, Becker N, Hartge P, Zheng T, Roman E, Holly EA, Boffetta P, Armstrong B, Cozen W, Linet M, Bosch FX, Ennas MG, Holford TR, Gallagher RP, Roll-inson S, Bracci PM, Cerhan JR, Whitby D, Moore PS, Leaderer A. Lai A, Spink C, Davis S, Bosch R, Scarpa A, Zhang Y, Severson RK, Yeager M, Chanock S, Nieters A. 2006 Genetic variation in TNF and IL10 and risk of non-Hodgkin lymphoma: A report from the InterLymph Consortium. Lancet Oncol 7:27-38. [PubMed: 16389181]

Shen M, Zhang LP, Lee KM, Vermeulen R, Hosgood HD, Li GL, Yin S, Rothman N, Chanock S, Smith MT, Lan Q. 2011 Polymorphisms in genes involved in innate immunity and susceptibility to benzene-induced hematotoxicity. Exp Mol Med 43:374-378. [PubMed: 21540635]

Skibola CF, Bracci PM, Halperin E, Conde L, Craig DW, Agana L, Iya-durai K, Becker N, BrooksWilson A, Curry JD, Spinelli JJ, Holly EA, Riby J, Zhang L, Nieters A, Smith MT, Brown KM. 2009 Genetic variants at 6p21.33 are associated with susceptibility to follicular lymphoma. Nat Genet 41:873-875. [PubMed: 19620980]

Thiel S, Kolev M, Degn S, Steffensen R, Hansen AG, Ruseva M, Jense-nius JC. 2009 Polymorphisms in mannan-binding lectin (MBL)-associated serine protease 2 affect stability, binding to MBL, and enzymatic activity. J Immunol 182:2939-2947. [PubMed: 19234189] 
Wang SS, Cozen W, Cerhan JR, Colt JS, Morton LM, Engels EA, Davis S, Severson RK, Rothman N, Chanock SJ, Hartge P. 2007 Immune mechanisms in non-Hodgkin lymphoma: Joint effects of the TNF G308A and IL10 T3575A polymorphisms with non-Hodgkin lymphoma risk factors. Cancer Res 67:5042-5054. [PubMed: 17510437]

Yang D, Chetov O, Bykovskaia SN, Chen Q, Buffo MJ, Shogan J, Anderson M, Schroder JM, Wang JM, Howard OM, Oppenheim JJ. $1999 \beta$-Defensins: linking innate and adaptive immunity through dendritic and T cell CCR6. Science 286:525-528. [PubMed: 10521347]

Zehnder A, Fisch U, Hirt A, Niggli FK, Simon A, Ozsahin H, Schlap-bach LJ, Ammann RA. 2009 Prognosis in pediatric hematologic malignancies is associated with serum concentration of mannose-binding lectin-associated serine protease-2 (MASP-2). Pediatr Blood Cancer 53:53-57. [PubMed: 19343776] 
TABLE I.

Demographic Characteristics of Cases and Controls in a Case-Control Study of NHL in Connecticut Women

\begin{tabular}{lrr}
\hline & Cases & Controls \\
Demographic characteristic & $\boldsymbol{n}=\mathbf{4 3 2}$ & $\boldsymbol{n}=\mathbf{4 9 4}$ \\
\hline Age (years) & & \\
$\quad<50$ & $86(20 \%)$ & $93(19 \%)$ \\
$50-69$ & $210(49 \%)$ & $212(43 \%)$ \\
$70+$ & $136(31 \%)$ & $189(38 \%)$ \\
Education & & \\
$<12$ years & $53(12 \%)$ & $55(11 \%)$ \\
12 years-College & $327(76 \%)$ & $368(74 \%)$ \\
Graduate or other & $52(12 \%)$ & $71(14 \%)$ \\
Family history of cancer ${ }^{a}$ & & \\
No & $88(21 \%)$ & $122(25 \%)$ \\
$\quad$ NHL & $9(2 \%)$ & $2(0.4 \%)$ \\
Other cancer & $335(78 \%)$ & $370(75 \%)$ \\
\hline
\end{tabular}

${ }^{a}$ Family history of cancer in first degree relatives. 


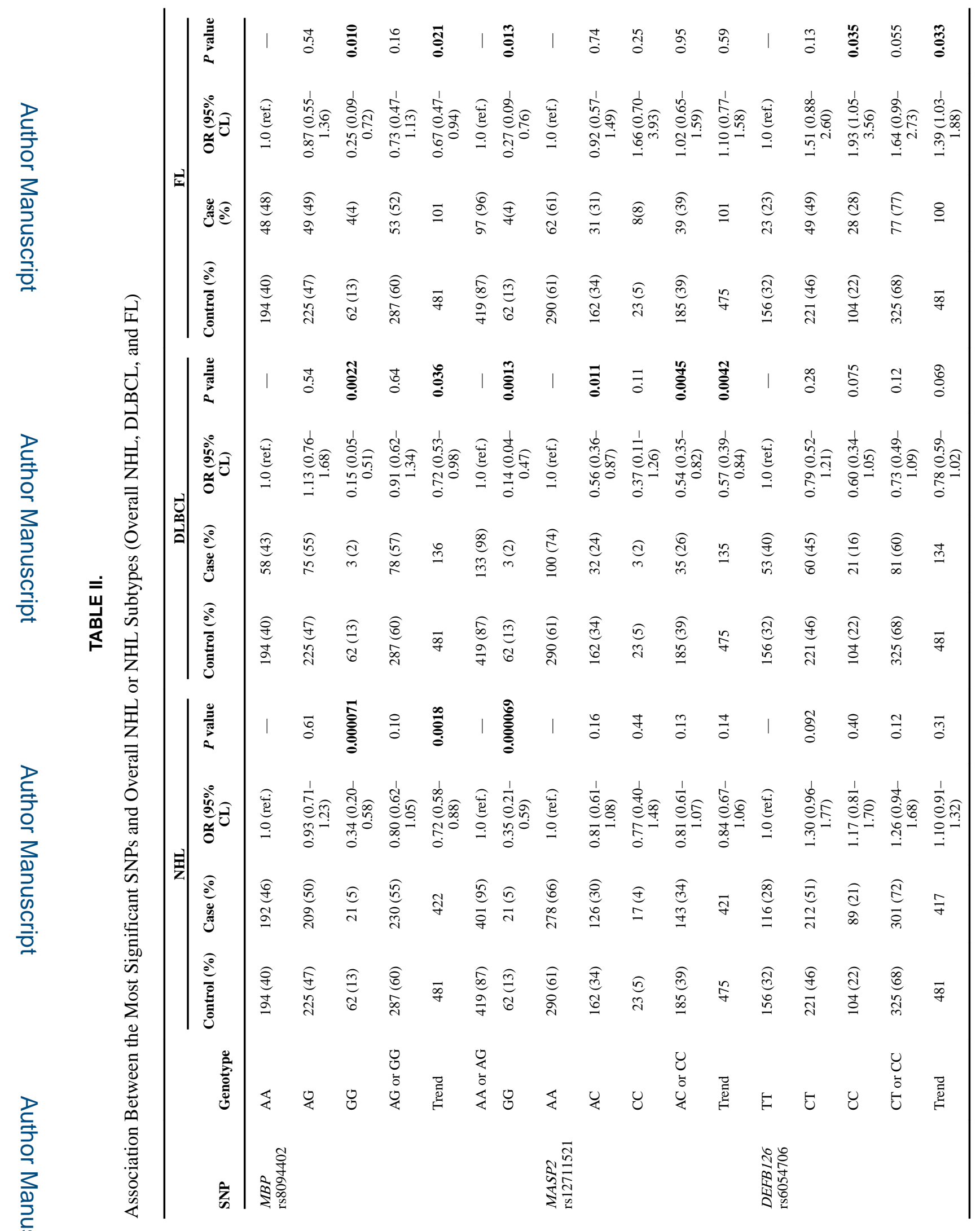




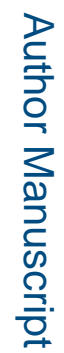

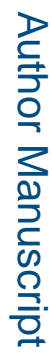

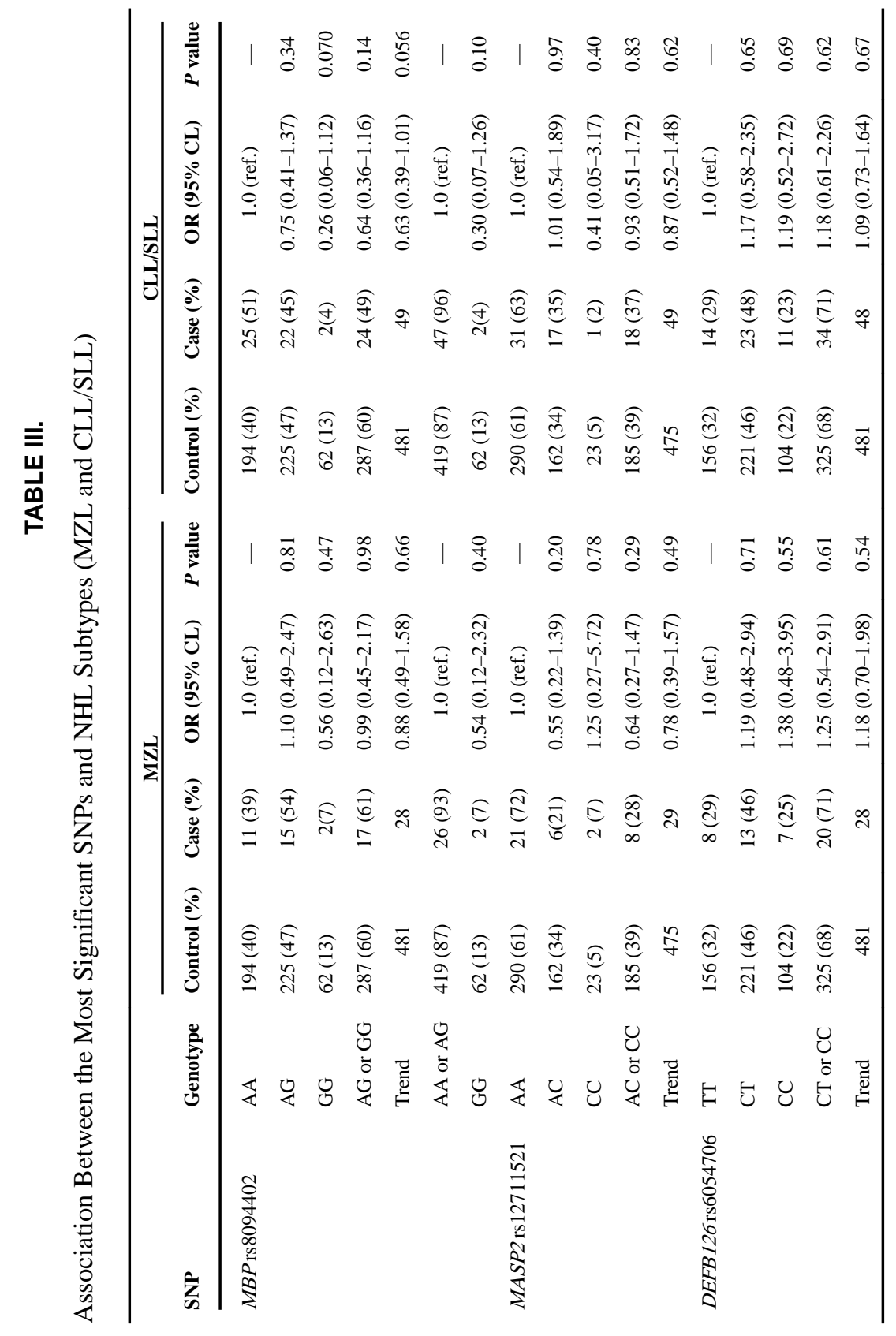

?

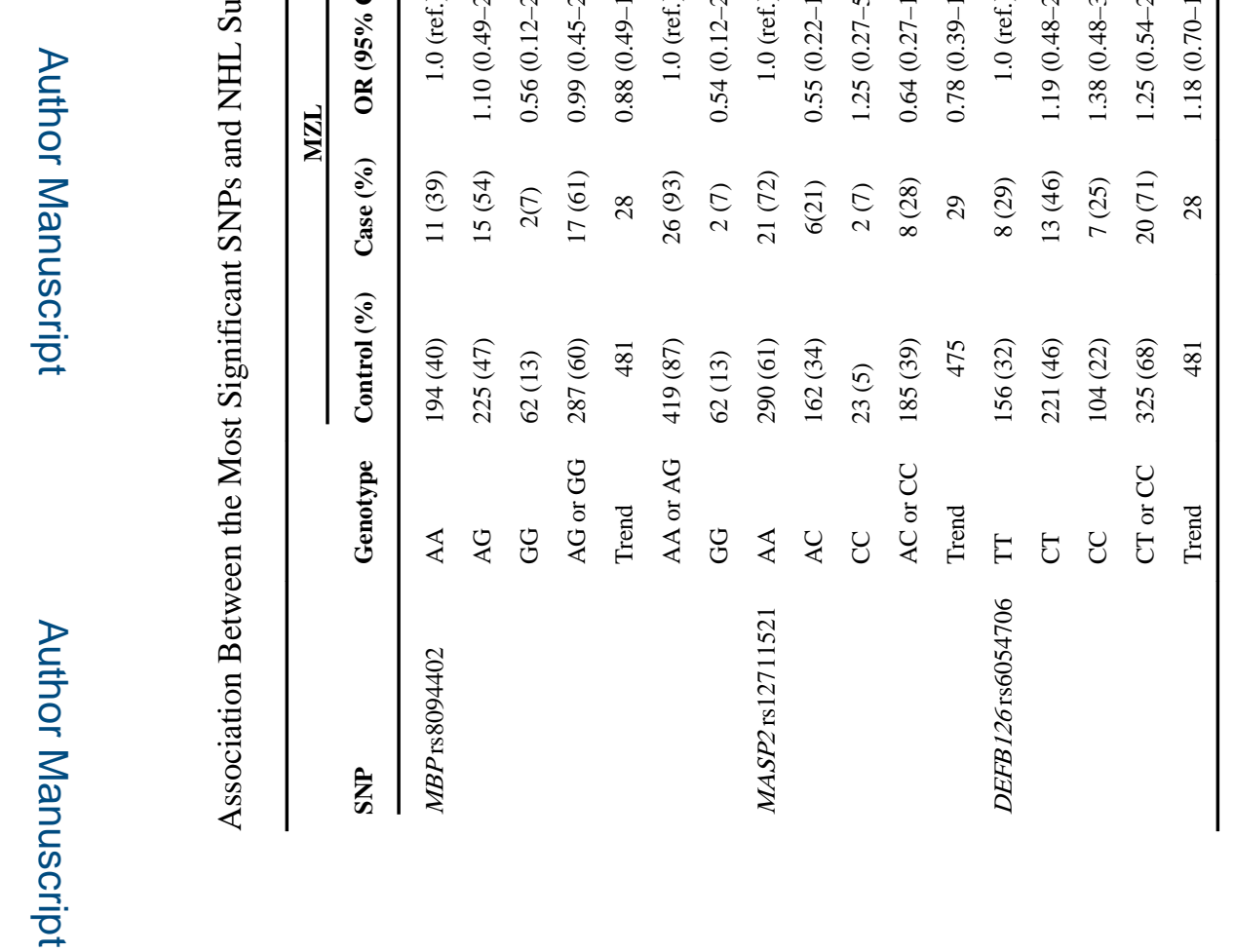

Environ Mol Mutagen. Author manuscript; available in PMC 2019 October 18. 